\title{
Controversies of Corruption
}

\author{
Fabian Zhilla (PhD)* \\ Lecturer, Business School, Canadian Institute of Technology
}

\section{Doi:10.5901/mjss.2015.v6n3p400}

\begin{abstract}
Corruption is widely conceived as producing negative effects for the society. However, there are still many controversial issues surrounding this phenomenon which may be seen critically. Some consider them the "positive" aspect of corruption. What can constitute corruption in public sector cannot be seen as such in the private sector. Research shows that corruption may not be as harmful for the society in certain stages of development. And yet financial instrument thought to stimulate the economy of a developing country may have adverse effect. Foreign aid has proved a vivid example. This research aims to broaden the prospect of a critical analysis of the role of corruption in society. To do that, this research will see corruption in the context of three sectors, the economy, public investments and foreign aid.
\end{abstract}

Keywords: corruption, developing countries, foreign aid.

"Indeed corruption is not a taboo topic, but one that policy makers, businesses, civil society organizations, media and donors from all regions are confronting openly"

\section{Introduction}

Corruption is perceived as one of the main factors rooting the economy worldwide. It has become a problem even in developed countries ( Jolly 2014). The study of corruption got attention of the researchers after the cold war. It was especially on the focus of the international organisations such World Bank in relation to the developing countries. The literature suggests that consequences of corruption are pervasive for the economy of the welfare of poor countries. Corruption's effects are both economic and political. Corruption may increases poverty, erodes public confidence in government, provokes political scandals, hinders private investments and likely to keep the society undeveloped in a prolonged stagnation. Corruption is widely conceived as producing negative effects for the society. However, there are still many controversial issues surrounding this phenomenon which may be seen critically. Some consider them the "positive" aspect of corruption. What can constitute corruption in public sector cannot be seen as such in the private sector. Research shows that corruption may not be as harmful for the society in certain stages of development. And yet financial instrument thought to stimulate the economy of a developing country may have adverse effect. Foreign aid has proved a vivid example. This research aims to broaden the prospect of a critical analysis of the role of corruption in society. To do that, this research will see corruption in the context of three sectors, the economy, public investments and foreign aid.

In the first part, the paper begins with the purpose of the institution (i.e. public or private) in determining whether a motive is ethically justified. The position of parties in a transaction which may involve corruption is crucial for perceiving that action as corrupt or not. In the second part, the research shows that the developing stage of the society should be considered very carefully before defining corruption as a malicious phenomenon. In the last part we move to the opposite side of the argument. We show that while corruption may have some "external" effects, there may be positive financial instruments for the development which may have an adverse effect if the process is corrupted. We take foreign aid as an example.

\section{The Concept of Corruption in Public and Private Sector}

According to Oxford Dictionary ${ }^{1}$ corruption is defined as: "Perversion or destruction of integrity in the discharge of public duties by bribery or favor; the use or existence of corrupt practices, esp. in a state, public corporation, etc". Or "the love of

1 Oxford Dictionary Online, Retrieved January 20, 2011, from http://dictionary.oed.com/cgi/entry/50050860?single=1\&query_type= word\&queryword=corruption\&first=1\&max_to_show=10. 
money is corruption of state' (Benjamin 1875). In other words corruption is regarded as a misuse of public trust, a situation which public officials use as a 'golden' opportunity to maximize their private income. It is also considered as a breach of official duty. Bureaucrats take advantage of their public position and put control on public goods.

Corruption may be defined differently when it comes to private sector. The concept of 'respecting' someone in a business relation is likely to be approached differently in a public service engagement. Whereas in the private sector a gift might be appreciated and hardly prejudiced, gift-giving in public administration may question the intention of gift-giver whether he is 'fishing' a favor from public service or his gift is given solely as a sign of respect. If the owner of a private enterprise helps his friend who manages another company by offering a subcontract to him, this favor can be defined as unjust favor if the same happens to a state agency.

Public administration is not driven by the same market concept. In a free market economy, government uses bureaucracy as an element supposedly to institutionalize public services thus making them legal. Therefore, what a private company pays to a public servant to smooth the procedures this is called a "facility payment". In public administration this is likely to be confined as bribery or kickoff (Ackerman 1999, p. 91). The concept of corruption is not uniform and this depends on the relation between private and public institutions. Both parties have different intentions and so is their perception on the transaction that may involve some sort of corruption. For instance, where the concept of favor exchanges sounds reasonable to a private business, this is not the case with public institutions. In other words what is approached as corrupt action by state institutions this may not be perceived similarly by a private business. The form of corrupted relations between private and state agencies is a significant indicator of the status of corruption in a society. Whether it is a bottom up corruption, meaning that private business 'coerce' to corruption, or a top down way, where the driving force for corruption are state agencies, this differs in different societies. In this regard defining corruption requires first, to establish what are the parties involved and their intentions and then classify actions as corrupted or not.

\section{Corruption Effects on the Society}

Majority of the analysts stipulate that the effects of corruption on a society are destructive. They go even further noting that corruption may be as deadly as HIVIAids virus (Bono 2006). However, in this section, the research intends to bring another view on the way corruption should be approached.

\section{Detrimental Effects of Corruption to Economic Growth}

Corruption hampers the free market. Government is in charge for collecting and distributing of tax revenues of the state, bearing the responsibility to administrate them properly. Allocation of these funds is in the discretion of public officials. A corrupt public administration diverts public funds to private business which is willing to "purchase" the access to them in exchange of kickbacks (Ackerman 1999, p 9). Public tenders are a good example. Substantial part of the government investments goes to infrastructure where private companies bid in open tenders or public procurements. Corrupt public officials allow illegal payments to determine the winner of these projects. One of the key forms of corrupting the public bureaucrat is bribes. Ackerman $(1999, \mathrm{p} 9)$ shows the negative effects of bribe in the free market.

She states that;

First, bribes strike the market which means that government can legalise allocation of scarce benefit to private sector by impeding them from a free competition. In other words, if government is bribed then the market will not be driven by the ratio between the demand and supply but by the best price offered by private parties to public administration for an easy access to public goods. While this is true, however, bribes can create a new "free market" in itself, the market of "bribes". In a sense the concept of the free market does not seem to be challenged here but what it seems troubled is the informality. The formal free market is substituted by an informal "free market". In this context the role of bribe is not that is evading the "free market" conceptually but that it makes relative. It parallels it with an "informal" free market. However, in an "informal" free market there is lack of accountability. The briber cannot accuse the bribed official.

Second, bribes act as motivation bonuses to public officials. Especially in developing countries where administration employees have low salaries, bribes may slow their incentive to perform public duties correctly for every one and direct their service only to them that offer the bribe. Again while this is also correct there may be something to be considered critically here. In countries with complicated laws or unclear legislation the bribe can help business to minimize the risk of time consuming. And this may help the economy grow.

Third, bribes lower costs. Private business can switch tax payments, custom duties or other utility bills to bribes if they result to be less expensive than paying regular governmental charges. While this is one negative facet of the bribe, another argument to be considered is that paying bribes may compete with paying taxes. And this will make the 
government change its policies. It may correct the tax system.

Forth, bribes help criminal activities to develop. Illegal business or criminal organisations purchase their 'freedom' by corrupting police forces or other sectors of the state. Again while this is a plausible argument, another one to be considered is that bribe may smooth aggressive forms of undermining the judiciary such as physical and physical harm of judges by criminals.

Earlier academics has contained that corruption constituted an extra-legal instrument which helps bypassing red tape barriers and allowing individuals or groups the admission to decision making process (Leff 1964). Taking the queuemodeling as an example Lui (1985) argues that bribes helps the queue to be rearranged more effectively. Thus, giving people, by purchasing(bribing the queue's manager) a better place in the queue, the chance to move up quicker in the queue setting( Leite and Weidmann 2002, p.162).

Back and Maher (1986) questioned claims on inefficiency of bribe and in defending their statement they compared the outcome of the bribe and competitive bidding in a government purchase arrangement. They find out that there is a fundamental isomorphism between them. The expected value of bribe was equal to expected value of the winning bid and they showed that the same supplier will be more likely to win the contract through both forms of payments. In support to earlier positive approaches there are even modern views loyal to the theory that corruption 'greases the wheels'. This favourable element of corruption works especially in societies with rigid regulations. Yet bribes, according to them, help entrepreneurship to overcome bureaucracy in order to accelerate into the market (Dreher and Gassebner 2007).

In a developing society where politics has to be fused by coherent ideas, where interests and groups are more inclined to be attached to political parties, corruption for Leys (1965) plays the political role of money which is to 'cement' social network relations within the political party or to fasten them. According to Khan (2006) it is not bribe but the 'predation corruption' which is the riskiest form of corruption for developing countries. Predation corruption is the typical scenario of patron-client system. Here public officials use their discretion power to gain in private what is public. It is not forced by any economical obstacle or from the lack of financial resources. It is pure greed and a top down corrupted system from senior state agents to the common public servants.

Many public investments such as highroad, hospitals, airports, enlargements of ports, water pipes lines, just name a few, are very expensive. They are very attractive for public officials to maximise their illicit incomes. Therefore corrupt actions may endanger even advantages identified by the economic experts when it comes to the role of public investment in the economic growth. They say that a strong economy needs capital and capital flow raises as more public investments are made (Tanzi and Davoodi 1998). In this respect a state which has high public investments is deemed to develop its economy quickly. Vito and Hamidi(1998) points out that:

\begin{abstract}
"Such corruption increases the number of capital projects undertaken and tends to enlarge their size and complexity. The result is that, paradoxically, some public investment can end up reducing country's growth because, even though the share of public investment in gross domestic product (the total of all goods and services produced in a country in a given year) may have risen, the average productivity of that investment has dropped."
\end{abstract}

However, even in the most dangerous form of corruption its negative elements may be questioned if other social factors are involved.

\title{
5. External Effects of Corruption
}

There is no standing scheme on corruption nor is it clear or unique; it various from country to country, from culture to culture and from one historical period to another (Huntington and Harrison 2000). There are various opinions about the impact of corruption in society. According to empirical studies some scholars have not seen corruption per se as the main factor for distortion of the society. What is significant they say is what the purchased product is in exchange of the payoff. Many economists and political scientists do not consider the small effects of the bribe's amount given to a common public official as significant but what really concerns them most is "the betrayal of ideals". In other words the legacy which corruption installs on the functioning of the society and its impact on ethical and moral norms is the biggest harm (Miller, William, Grodelan and Koshechkina(2001). For instance political corruption can be more danger for open public than a small bribe given to a public employer. Where, the former risks capturing of the state, the latter may have limited effects on the economy as whole.

Nonetheless, bribes can also be seen as having positive roles in the early stages of emerging economies. In many Eastern Asian countries the economic boom could not have been successful without some sort of corruption. J. Edgardo Campos in his editing volume (Corruption: The Boom and Bust of East Asia, 2001), points out that; "Rents and corruption 
have been essential to the credible enforcement of contracts and thus to the large inflows of investment." (Filomeno 2006) In addition, China, Vietnam and India have experienced a stead increase of investments and economic growth in spite of corruption. In this regard Khan has classified corruption in developing countries from an interesting perspective (Filomeno 2006, p.5).

First, intervention of government in certain processes of economic development has been wrongly perceived as malicious and as creating an addition possibility for public sector to accelerate corruption. Instead of market liberalisation or privatisation, the involvement of the state through rent seeking has been central in order for the governments to maintain a stable welfare and to control corruption (Filomena 2006, p.5). As the result Asian countries for instance yielded successful results especially in the technology implementation policy.

Second, corruption is not always a derivative of greed and inappropriate use of power by public servants. Fiscal constrains like trade protection or custom policies for supporting indigenes agriculture, are an important factor to enhance and develop the economy. If the economy is stable so is the political system. However, while in developed countries salaries are high and unemployment rate is low, emerging economies, however face off- budgets and jobs shortage. In this regard the risk of patron-client relationship is high. Here public servant obey to his 'patron' and the latter in exchange turns a blind eye for the pay offs to the former by privates as compensations for low salaries. Therefore, it can be assumed that probably the stage of development and economic factors may condition the government to tolerate petty bribes in order to maintain political stability.

Third, scarce protection of property rights is also another symptom of corruption in developing countries. However, as above mentioned, economic power is again the core reason. Khan underlines that the cost applied for an immediate reform to property rights protection can affect the economy and disrupt the system as the productivity is low and unable to cover the costs of property rights' protection. Filomeno $(2006$, p.5) points out that;

"...as the examples again of China or Vietnam show2, informal institutional arrangements, including innovative incentive mechanisms, can substitute for the lack of formal property rights, with satisfactory outcomes to both the individual and the collective."

In this context, corruption may facilitate economic enhancement in early stages of the democracy in an emerging economy ${ }^{3}$. Many developing countries like China and India, known for their extensive corruption, yet are not struggling with their permanent economic growth. This is an important indicator showing that probably corruption has some external effects. In other words, studying corruption may be more accurate if other social factors like political system, democracy maturity, history and culture are to be taken into account.

\section{Corruption in Development Assistance}

We argued that in analysing a factor which harms the economy of a society such as corruption someone should look at the political and social context. Not every unfair perceived form of enrichment is always harmful. In contrary not every good perceived financial tools are always helpful. Development assistance is playing a crucial role in assisting developing countries to enhance their socio-economic process. Development assistance differs in motives, actors and budgets (Tisch and Wallace 1994). It generally transfers large amounts of capitals from donors to recipients in terms of goods and foreign exchanges. National governments have the advantage of being directly involved in the management of these projects and this discretion may lead them to misuse foreign aid. The question arises what is the relation between foreign aid and corruption?

Foreign aid can help corrupt regimes to retain their power and control. Since foreign aid goes from one government to another, notes Di Lorenco (2005), 'it inevitably diverts resources from the activity of production to the activity of "rent seeking" or attempts to acquire governmental funds'. He further continues that 'it creates a giant patronage machine, in other words, with all the attendant corruption that such things have always entailed.' Hence corruption remains a great

\footnotetext{
2 World Bank. (2006). Annual Review of Development Effectiveness, (p. .xii). Washington D.C.

${ }^{3}$ Democracy is defined as 'Government by the people; that form of government in which the sovereign power resides in the people as a whole; or A state or community in which the government is vested in the people as a whole (Oxford Dictionary Online), Or 'The democracy is a system of governance, but which is free is an individual. An individual is free not just because the system of government is democratic but because none of other organizations of society can fiercely restrict that individual." (Weaver H. James 1996). See also that democracy is openness. (Wintraub Sidney1991). This includes economic and political openness.
} 
concern in developing projects. The reason is that national government has limited budget and low salary for their employers. As development projects involve tenders, procurement and administrative procedures, public officers find difficult to resist the temptation of bribes which usually is equal or more to their annual salaries. In this respect instead of allocating the aid to development projects, public workers use them for their unjust enrichment. Looking to vulnerability of the foreign aid to corruption, many people have questioned the way foreign aid is organised. Mark Thornton (2002) points out that:

"Alas, Americans are united in their opposition to foreign aid-and with good reason! Foreign aid, military aid, debt relief, economic development assistance, and even disaster assistance money-all with "strings attached" to ensure proper behavior-are associated with "fraud, waste, and abuse."

On the other hand, many potential donors argue that occasionally corruption is an instrument used to protect their business in developing countries (Thornton 2002). E.g. in 1994, French companies estimated to have paid bribes amounting to FF 10 billion and German companies more than \$3 billion per year in 1996 (ibid). Yet many donors condition the aid by requesting recipients to fulfil various criteria such as enhancing of democratic values ${ }^{4}$ and strengthen public institutions ${ }^{5}$ aimed at increasing transparency, accountability and reduction of corruption. Donors assert that weak governments are unable to manage and enforce anti-corruption reforms. Can aid directed at strengthening of state institutions be at risk in a fragile democracy? Providing foreign aid to empower state institutions in the main stream economy may endanger private sector's position as former can extend the power through regulation or enforcement agencies to control the market. This controversial disadvantage of foreign aid is explained by Saxton (1999) who points out that:

\begin{abstract}
"Literature dealing with foreign economic aid recognizes that government-to-government foreign economic assistance often can (inadvertently) promote those conditions that foster corruption. This is especially the case when a significant degree of corruption is already present in recipient countries."
\end{abstract}

The 'foreign aid fear' of Saxton is based on the Tanzy's hypothesis arguing that extended power of government in economy may lead to corruption. The 'extend power' usually refers to increase of taxation, raise of public spending and extension of regulation on part of the government. Thus, Tanzi claims that the above areas where corruption is mostly present can gradually become norm of behavior especially in countries with no democratic traditions. The government may have a different perception of enforcing the rule of law. They can presume that corruption can be reduced by limiting of public spending including salaries to officials based on assumption that public workers take bribes (routine perception), rather than punishing them (rule of law perception) (Tanzi 1998, p.6). In this context, the role of foreign aid in reducing corruption remains questionable. Evidences gathered by Alesina and Weder (2002) showed that corrupt governments don't appear to get less aid. In contrary boost of aid in developing countries was accompanied by raise of corruption. Alesina and Weder (2002, p.1130) point out that:

\begin{abstract}
"The variable "changes in aid has a negative and statistically significant coefficient, indicating that an increase in aid is associated with an increase in corruption and vice versa in that corruption appears to be persistent, since the log dependent variable is highly significant."
\end{abstract}

In short foreign assistance can play a crucial role in improvement of socio-economical factors of a developing country. However it should also be mentioned that developing aid can stimulate corruption or strengthen corrupt political regimes. According to Alesina and Weder (2002) the ratio between foreign assistance and corruption stands positive meaning that increase of aid has been associated permanently with the raise of corruption.

\title{
7. Conclusion
}

Corruption is entrenched in the economy worldwide and is more evident in developing countries. Approaching corruption and its consequences to the society may entail various factors in order to sort out phases where corruption is likely to hamper the development and phases where it may not. Thus the role of corruption in the society is controversial. Corruption may distort the free market or make public investment inefficient to increase economic growth. On the other

4USAID. Final Report. Effects of U.S. Foreign Assistance on Democracy Building form http://blackboard.gwu.edu/webapps/portal /frameset.jsp?tab=courses\&url=/bin/common/course.pl?course_id=_101218_1

${ }_{5}^{5}$ World Bank (2000, November). Reforming Public Institutions and Strengthening Governance, (pp. xi-xx) Washington, DC; World Bank 
hand, corruption may facilitate development in emerging economies in early stages of democracy. In order to have a clear picture of corruption's role in the society one may consider social factors like political system, maturity of democracy, history, economy and so forth. Studies of anti-corruption policies may be enriched if a more nuanced approach about the role of corruption on certain stages of the society's development will be considered.

\section{References}

Ackerman-Rosse, Susan ( 1999 ). "Corruption and Government; Causes, Consequences and Reform" Cambridge University Press.

Alesina Alberto \& Weder Beatrice (2002). 'Do Corrupt Governments Receive Less Foreign Aid? The American Economic Review, Vol. 92, No. 4 (Sep., 2002), pp. 1126-1137.

Belton Catherine and Buckley Neil (2007) "Investing in Russia; Corruption Complicates An Image Problem" Financial Times, October 2, 2007.

Di Lorenco, J Thomas (2005). "A Foreign Aid Disaster in the Making", Lodwig von Mises Institute.

Filomeno S. Sta. Ana III (2006). "YELLOW PAD; Fighting corruption needs more than a 'spray gun' Business World, October 2, 2006 Monday, Pg. S1/5

Huntington P. Samuel, and Harrison E. Lawrence (2000). "Culture Matters: How Value Shape Human Progress" Basic Books,New York, USA p.112-113.

Kenny Charles (2007) "Construction, Corruption and Developing Countries" World Bank Policy Research Working Paper 4271, June 2007, World Bank, Washington D.C. USA.

Khan H. Mustaq (2006). "Governance and Anti-Corruption Reforms in Developing Countries: Policies, Evidence and Ways Forward".

Levis James (2005). "Earthquake Destruction; Corruption on the Fault Line", Global Corruption Report 2005.

Miller L. William, Grodelan B. Ase and Koshechkina Y. Tatyana (2001). " A Culture of Corruption?; Coping With Government in Post Communist Countries" Central European University Press, p.14

Mufson Steven (2007) "Oil Prices Rise Causes Global Shift in Wealth; Iran, Russia and Venezuela Feel the Benefits" The Washington Post, November $10^{\text {th }} 2007$ p.A01.

Poroznuk Amber (2007), Spotlight Story; Transparency Watch, October 2007 Transparency International.

Saxton Jim (1999). "Can IMF Lending Promote Corruption" Joint Economic Committee Studies, United States Congress.

Tanzi Vito (1998). "Corruption Around the World, Causes, Consequences, Scope and Cure" IMF Working Paper, WP/98/63, p. 5 International Monetary Fund, Washington D.C.

Tanzi Vito and Davoodi Hamid (1998). "Roads to Nowhere: How Corruption in Public Investment Hurts Growth" International Monetary Fund Papers, Washington D.C.

Tisch J. Sara, \& Wallace B. Michahel (1994) "The What, Why, and Who of Foreign Aid", Westview Press Inc, Colorado, USA, p 49-87.

Transparency International "Global Corruption Barometer 2006" Transparency International, Berlin Germany.

The New York Times "China's Paradox Corruption" at The New York Times, March 61998.

Thornton Mark (2002). "Corruption and Foreign Aid", Lodwig von Mises Institute

USAID 'USAID Final Report on "Effects of U.S. Foreign Assistance on Democracy Building' USAID, Washington D.C.

Jowett, Benjamin (1875). The dialogues of Plato tr. 1871. Thucydides tr. 1881.

Weaver H.James and Rock, T. Michael, (1996) "Achieving Brad Based Sustainable Development" ch. 4 p.85.

World Bank "Annual Review of Development Effectiveness 2006", World Bank, Washington D.C. p. .xii.

World Bank, "Governance and Anticorruption Strategy 2007" World Bank, Washington D.C.

World Bank "Reforming Public Institutions and Strengthening Governance; A World Bank Strategy", ,World Bank, Washington, DC, November 2000 p. xi-xx.

World Bank "World Bank's Strategy 2007" World Bank, Washington D.C.

World Bank, (1997) "Overview" The State in Changing World- World Development Report, New York, Oxford Press for the World Bank 